\section{Diatoms in a future ocean - stirring it up: reply from Falkowski and Oliver}

\section{Paul G. Falkowski and Matthew J. Oliver}

We have suggested that future warming climate scenarios will result in a shift in the phytoplankton community in the central ocean gyres towards smaller cells, and that under such conditions, diatoms, especially large-celled species, would be at a competitive disadvantage ${ }^{1}$. We also suggested that a warming climate will simultaneously enhance the productivity of large phytoplankton, such as diatoms, in coastal regions, owing to increased wind-driven upwelling ${ }^{1}$. Peters claims that our suggestion is uncertain, arguing that climate and biological-modelling efforts show that future warming climate scenarios will result in conditions that favour diatoms.

First, we agree with Peters that our proposal of future phytoplankton-population dynamics is not certain. Unfortunately, certainty is not an attribute of future climate prediction, and therefore simply demonstrating that there is uncertainty in a prediction cannot be used as a test to reject our basic hypothesis. Rather, what is necessary is an assessment of climate-forced environmental conditions that allow one phytoplankton group to out-compete other phytoplankton groups. We suggest that future warming climate scenarios generally lead to increased stratification in the central gyres, which, if true, is predicted to reduce the competitive advantages of diatoms ${ }^{2}$. If that happens, small-celled phytoplankton will have a competitive advantage over large-celled phytoplankton. This does not mean, however, that diatoms will be absent; rather, diatoms will probably become a smaller component of the phytoplankton community.

Peters provides two examples of how warming climate scenarios might lead to a less-stable upper ocean that favours diatoms and an export flux of organic matter: increased storms and chaos in the upper mixed layer. Indeed, these two phenomena could increase the turbulent energy in the upper ocean, and thus potentially enhance export production; however, even if this were to occur, the feedback effect on the climate would be small. As Peters also points out, warming climate scenarios depend on the integrated balance of stabilizing versus destabilizing events in the open ocean. This is an onerous modelling task that can have uncertain results owing to the number of parameters that are required to estimate the balance of stabilizing and destabilizing events in future climate scenarios.

Ultimately, it is the geological record and ecological observations that inform models ${ }^{3,4}$. The geological record suggests that as climate warms the upper ocean becomes more stabilized, with a greater abundance of small coccolithophorids and smaller diatoms ${ }^{5}$. It is possible that the current warming event might not unfold as historical record suggests; however, the geological record remains one of the best sources of empirical evidence from which to evaluate and predict the effect of climate change on the ocean environment. Similarly, during glacial-interglacial cycles, there seems to be an alteration between diatoms and coccolithophorids ${ }^{6,7}$. Finally, recent ecological observations suggest that the central gyres have become increasingly oligotrophic ${ }^{8-10}$.

In summary, models are inevitably imperfect. However, based on the geological record and ecological observations, we contend that in the coming centuries the ocean will favour small cells and fewer diatoms than that observed prior to the industrial revolution.

Paul G. Falkowski is at the Institute for Marine and Coastal Sciences, Rutgers University, 71 Dudley Rd, New Brunswick, 08901 New Jersey, USA and at the Department of Geological Sciences, Rutgers University, Wright-Rieman Laboratories, 610 Taylor Road, Piscataway, 08854 New Jersey, USA.

Matthew J. Oliver is at the College of Marine and Earth Studies, University of Delaware, 700 Pilottown Rd. Lewes, 19958 Delaware, USA.

Correspondence to P.G.F. e-mail: falko@marine.rutgers.edu

1. Falkowski, P. J. \& Oliver, M. J. Mix and match: how climate selects phytoplankton. Nature Rev. Microbiol. 5, 813-819 (2007).

2. Bopp, L. et al. Response of diatoms distribution to global warming and potential implications: a global model study. Geophys. Res. Lett. 32, L19606 (2005).

3. Falkowski, P. G. et al. The evolution of modern eukaryotic phytoplankton. Science 305, 354-360 (2004).

4. Litchman, E. in Evolution of Aquatic Photoautotrophs (eds Knoll, A. H. \& Falkowski, P. G. ) 351-375 (Academic, New York, 2006).

5. Katz M. E., Finkel, Z. V., Grzebyk, D., Knoll, A. H. \& Falkowski, P. G. Evolutionary trajectories and biogeochemical impacts of marine eukaryotic phytoplankton. Annu. Rev. Ecol. Evol. Syst. 35 523-556 (2004).

6. Falkowski, P., Barber, R. \& Smetacek, V. Biogeochemical controls and feedbacks on ocean primary production. Science 281, 200-206 (1998)

7. Iglesias-Rodriguez, D. M. et al. Representing key phytoplankton functional groups in ocean carbon cycle models: coccolithophorids. Global Biogeochem. Cycles 16, 1100 (2002).

8. Falkowski, P. G. \& Wilson, C. Phytoplankton productivity in the North Pacific ocean since 1900 and implication for absorption of anthropogenic $\mathrm{CO}_{2}$. Nature 358, 741-743 (1992).

9. Behrenfeld, M. J. et al. Climate-driven trends in contemporary ocean productivity. Nature 444 752-755 (2006)

10. Polovina, J. J., Howell, E. A. \& Abecassis, M. Ocean's least productive waters are expanding. Geophys. Res. Lett. 35, L03618 (2008). 